\title{
Isolation and Antibiogram of Shiga Toxin-Producing Escherichia coli 0157:H7 from Diarrhoeic HIVIAIDS Patients in Lafia, Central Nigeria
}

\author{
Reuben, C.R. ${ }^{1 *}$ and Gyar, S.D. ${ }^{1,2}$ \\ ${ }^{1}$ Dept. of Sci. Lab. Tech., Nasarawa State Polytechnic, Lafia, Nigeria. \\ ${ }^{2}$ Dept. of Biological Sciences, Nasarawa State University, Keffi, Nigeria \\ *Corresponding Author's Email: reubenrine@yahoo.com
}

\begin{abstract}
This study assessed the prevalence and antibiogram of Shiga Toxin-Producing Escherichia coli 0157:H7 from Diarrhoeic HIVIAIDS Patients in Lafia, Central Nigeria. E. coli O157:H7 from stools of consenting HIVIAIDS patients were isolated by culture based, biochemical and serological assays. Confirmed isolates were tested for their susceptibility to commonly used antimicrobial agents using the disk diffusion method as described by the Clinical and Laboratory Standards Institute (CLSI). The prevalence of E. coli 0157:H7 from Diarrhoeic HIVIAIDS patients was $1.9 \%$ of which $33.3 \%$ and $66.7 \%$ were from males and females respectively. The cumulative antibiotic resistance frequency of the isolates was $56.7 \%$. All the $3(100 \%) \mathrm{E}$. coli $0157: \mathrm{H} 7$ isolates were resistant to Amoxicillin and Augmentin, 2(66.7\%) to Cotrimoxazole, Sparfloxacin, Ofloxacin and Streptomycin. The isolates showed lower frequencies of resistance to Chloramphenicol (33.3\%), Ciprofloxacin (33.3\%), Gentamicin (33.3\%), and Pefloxacin (0.0\%). Resistance phenotypes recorded were: Cotrimoxazole-ChloramphenicolSpafloxacin-Ciprofloxacin-Amoxicillin-Augmentin-Streptomycin; Spafloxacin-Amoxicillin-AugmentinGentamicin-Ofloxacin and Cotrimoxazole-Amoxicillin-Augmentin-Ofloxacin-Streptomycin with the same frequency (33.3\%). There was joint resistance of $E$. coli 0157:H7 isolates to almost all antibiotics tested, with the Multiple Antibiotic Resistance (MAR) index of 0.5 and 0.7 which indicates that these isolates were exposed to these antimicrobial agents. The high degree of antibiotic resistance and MAR indices suggests the need for continuous surveillance of antimicrobial resistance trends in immunocompromised patients who are highly susceptible to opportunistic infections with Shiga ToxinProducing E. coli 0157:H7.
\end{abstract}

Key words: Multiple antibiotic resistance, Escherichia coli O157:H7, HIVIAIDS, diarrhoea

\section{INTRODUCTION}

Shiga toxin-producing Escherichia coli (STEC) or Verotoxigenic producing strains of Escherichia coli (VTEC) are recognized as an important human pathogen of public health concern (Bettelheim and Beutin, 2003). Since its first recognition, this serotype and its isolation from stool samples have sharply increased, and ranked as the $3^{\text {rd }}$ most common bacterial pathogen of the human gut after Salmonella and Campylobacter spp (Riley et al., 1983; Fitzpatrick, 1999; Adwan et al., 2002).

Although a variety of $E$. coli serotypes have been associated with human illness, the most important among these is $0157: \mathrm{H} 7$. Enterohaermorrhagic E. coli $0157: \mathrm{H} 7$ is one of the six groups of $E$. coli recognized as an etiological agent of diarrhoea (Aboaba et al., 2006). Infection with this $E$. coli serotype is associated with a spectrum of illnesses including watery diarrhoea, bloody diarrhoea, and the haemolytic uremic syndrome, a potentially fatal condition characterized by acute renal failure (Griffin and Tauxe, 1991). Cattle are the principal reservoir for these organisms. Important sources of infection include consumption of undercooked hamburger, ground beef, raw milk, meat and dairy 
products, vegetables, unpasteurized fruit juices and water, and other contaminated food products (Chapman et al., 1997; Wilson et al., 1997). Infection can also be acquired by direct contact with animals and by person-toperson spread (Cho et al., 2006).

Diarrhoea occurs in about 30 to $60 \%$ of HIVIAIDS patients in developed countries and in an estimated $90 \%$ of such patients in developing countries (Sapkota et al., 2004). Epidemiological investigations during outbreaks have identified $E$. coli $\mathrm{O} 157: \mathrm{H} 7$ as a pathogenic strain that causes severe and life-threatening diarrhoea (Galane and Le Roux, 2001). E. coli O157:H7 infections pose the greatest risk to immuno-suppressed individuals because it can easily invade the cells of HIVIAIDS patients due to a suppressed cell-mediated immunity (Morris and Potter, 1997; Hoffman, 2004).

Awareness of the clinical and therapeutic aspects of diarrhoea suspected to have been caused by $E$. coli O157:H7 in HIVIAIDS patients is therefore vital in directing diagnostic evaluation of these patients and further research to improve human health. This strain of $E$. coli is a threat to human health, especially to immunocompromised persons such as HIVIAIDS patients, as the bacteria can be contracted from foods and water consumed by these patients. Also because of a compromised immune system, such patients may develop diarrhoea attributed to $E$. coli $\mathrm{O} 157: \mathrm{H} 7$ than it would be the case for immuno-competent persons (Abong et al., 2008).

Although, antibiotics are not recommended for treatment of $E$. coli O157: $\mathrm{H} 7$ infections in humans, there is evidence that bacterial isolates are resistant to some antibiotics (Aibinu et al., 2007). However, such treatments may be recommended for cystitis and pyelonephritis other than haemorrhagic colitis all caused by E. coli O157:H7 (Griffin and Tauxe, 1991). For those limitations of using antimicrobial agents in $E$. coli O157:H7 cases, the generally accepted belief is that $E$. coli 0157:H7 may still be susceptible to most antimicrobials. In addition to their epidemiological importance, the studies of antimicrobial susceptibility of E. coli O157:H7 may have more therapeutic significance as recent studies have indicated a possible role of early administration of antimicrobials in preventing the progression of haemolytic uremic syndrome and haemorrhagic colitis both caused by E. coli O157:H7 (Molbak et al., 2002).

To the best of our knowledge, there is no study that has elucidated the presence and antibiogram of $E$. coli O157:H7 from diarrhoeic HIVIAIDS patients in Lafia, Central Nigeria. Unfortunately, the diagnosis of $E$. coli O157: H7, in spite of its role in diarrhoea and its potentially severe outcome, is not considered a routine laboratory test in the study area, and there are no comprehensive and documented data on the incidence and prevalence of diarrhoea caused by this particular strain. This study thus investigated if $E$. coli $\mathrm{O} 157: \mathrm{H} 7$ is one of the bacteria involved in diarrhoea that habitually characterize HIVIAIDS patients. The antimicrobial susceptibility profiles of $E$. coli O157:H7 isolates obtained from the stools of these patients were also investigated.

\section{METHODS}

\section{Study Population and Area}

This study was carried out among confirmed HIVseropositive patients with diarrhoea who presented in Dalhatu Araf Specialist Hospital (DASH) Lafia, Central Nigeria. The study area was selected based on the researchers' familiarity with the area, HIV prevalence and the presence of a referral hospital, DASH, which is situated in Lafia, Nasarawa State capital and caters for HIVIAIDS patients of various races, gender and age groups from various Local Government Areas, districts and rural areas within and outside the State. According to the recent National HIVIAIDS Reproductive Health Survey, Nasarawa State has a very high prevalence (8.1\%) of HIVIAIDS in Nigeria after Kaduna, Taraba and Rivers States with the prevalence of $9.2 \%, 10.5 \%$ and $15.2 \%$ respectively (NARHS, 2012).

The study commenced after ethical approval was obtained from the hospital ethical committee. Informed consent was also obtained from each of these patients. The study period was between May, 2014 and June, 2015.

\section{Sample Collection}

One hundred and sixty (160) fresh stools specimen were obtained from confirmed HIVIAIDS positive patients visiting DASH for treatment, using sterile plastic universal container (Sterilin, UK), and returned to the laboratory immediately. The confirmed HIVIAIDS patients had already been tested for HIV at the HIVIAIDS clinic of DASH and were known by the hospital clinicians to be carriers of the virus. The patients' diarrhoeal condition and HIVIAIDS status were recorded. Anonymity of the patients was protected as much as possible. Diarrhoeic stools in this study were diagnosed in the case of patients experiencing three or more watery stools in 24 hours. Patients included children, adults and the elderly. Detailed history to define age, sex and location of patients were documented.

\section{Selective Plating and Identification of E. coli $0157: \mathrm{H} 7$ Colonies}

A loop full of each stool specimen was cultured for $E$. coli on Eosin Methylene Blue Agar (Oxoid CM 0069) and incubated at $44^{\circ} \mathrm{C}$ for $24 \mathrm{~h}$ as described by Okeke et al. 
22 Int. Res. J. Microbiol.

Table 1. Prevalenceof E. coli O157: $\mathrm{H} 7$ from diarrhoeic HIVIAIDS patients in Lafia, Central Nigeria

\begin{tabular}{lcc}
\hline Feature & No. (\%) of Samples Tested & No. (\%) Positives \\
\hline Age & $9(5.6)$ & $1(33.3)$ \\
$<10$ & $18(11.3)$ & $0(0.0)$ \\
$11-20$ & $47(29.4)$ & $0(0.0)$ \\
$21-30$ & $53(33.1)$ & $0(0.0)$ \\
$31-40$ & $17(10.6)$ & $1(33.3)$ \\
$41-50$ & $16(10.0)$ & $1(33.3)$ \\
$51>$ & & \\
Gender & $71(44.4)$ & $1(33.3)$ \\
Male & $89(55.6)$ & $2(66.7)$ \\
Female & & \\
Location & $58(36.3)$ & $2(66.7)$ \\
Urban & $69(43.1)$ & $1(33.3)$ \\
Suburban & $33(20.6)$ & $0(0.0)$ \\
Rural & $160(\mathbf{1 0 0 . 0})$ & $\mathbf{3 ( 1 . 9 )}$ \\
\hline Total & & \\
\hline
\end{tabular}

(2001) and screened for E. coli O157:H7 on Sorbitol MacConkey Agar (Oxoid, CM813) enriched with Cefixime-Tellurite supplement (Oxoid SR 172).E. coli colonies have green metallic sheen appearance on EMB while typical E. coli O157:H7 appeared as non-sorbitol fermenter colonies (NSFC) which are characterized as having a slightly transparent, almost colourless with a weak pale brownish appearance on CT-SMAC. Discrete colonies were randomly selected and then examined for the presence of gram-negative rods using Gram staining technique (Prescott et al., 2005).

\section{Biochemical Test}

The strains were characterized biochemically using Microbact 12E (MB1130At, Oxoid) according to the manufacturer's instruction. Identification of $E$. coli strains was done following a series of 12 biochemical tests.

\section{Serological Test}

Presumptive E. coliO157:H7 colonies were serologically confirmed by using $E$. coli $\mathrm{O} 157: \mathrm{H} 7$ latex agglutinations assay (R30959601, Oxoid), containing latex particles coated with antibodies specific for E. coli 0157 and $E$. coli $\mathrm{H} 7$ antigen. Isolates were tested separately with anti$\mathrm{O} 157$, and $\mathrm{H} 7$ antisera. Identification of $E$. coli $\mathrm{O} 157: \mathrm{H} 7$ was carried out following the manufacturer's instruction, hence colonies that agglutinated to the separate antisera were considered to be E. coli O157: $\mathrm{H7}$.

\section{Antimicrobial Susceptibility Test}

All E. coli O157: $\mathrm{H}$ 7isolates were tested for antimicrobial susceptibility by disk diffusion technique in accordance to Clinical and Laboratory Standards Institute (CLSI) criteria (CLSI, 2007) using multi-antibiotic discs (Maxicare Medical Laboratory, Nigeria) containing the following antimicrobials and disc content (in $\mu \mathrm{g}$ ): Cotrimoxazole $(30 \mu \mathrm{g})$, Chloramphenicol $(30 \mu \mathrm{g})$, Ciprofloxacin $(10 \mu \mathrm{g})$, Amoxicillin $(30 \mu \mathrm{g})$, Augmentin $(30 \mu \mathrm{g})$, Gentamicin $(10 \mu \mathrm{g})$, Pefloxacin $(\mu \mathrm{g})$, Ofloxacin $(10 \mu \mathrm{g})$, Streptomycin $(30 \mu \mathrm{g})$, Sparfloxacin $(10 \mu \mathrm{g})$. E. coli ATCC 25922 was used as control organism, and the results were interpreted using the CLSI criteria (CLSI, 2007).

\section{RESULTS}

\section{Prevalence of E. coli O157:H7}

The prevalence of $E$. coli O157: $\mathrm{H} 7$ from diarrhoeic HIVIAIDS patients in Lafia, Central Nigeria is $1.9 \%$, with 33.3 and $66.6 \%$ from males and females respectively. With respect to age groups, patients within the age group $<10,41-50$ and $51>$ had the prevalence of $33.3 \%$ while those within 11- 20, 21- 30, and 31- 40 age groups had $0.0 \%$. The prevalence of E. coli O157: $\mathrm{H} 7$ among urban, suburban and rural dwellers was 66.7, 33.3 and $0.0 \%$ respectively (Table 1 ).

\section{Antimicrobial Resistance}

All the isolates were resistant to most of the antibiotics. 
Table 2. Antimicrobial susceptibility of $E$.coli O157:H7 isolates from diarrhoeic HIVIAIDS patients in Lafia, Central Nigeria.

\begin{tabular}{lccc}
\hline & \multicolumn{3}{c}{ Susceptibility (n= 3) } \\
\cline { 2 - 4 } & $\mathbf{R}$ & $\mathbf{I}$ & $\mathbf{S}$ \\
Antibiotic & No. (\%) & $0(0.0)$ & No. (\%) \\
\hline Cotrimoxazole & $2(66.7)$ & $0(0.0)$ & $1(33.3)$ \\
Chloramphenicol & $1(33.3)$ & $1(33.3)$ & $2(66.7)$ \\
Sparfloxacin & $2(66.7)$ & $0(0.0)$ & 0 \\
Ciprofloxacin & $1(33.3)$ & $0(0.0)$ & $2(66.7)$ \\
Amoxicillin & $3(100.0)$ & $0(0.0)$ & 0 \\
Augmentin & $3(100.0)$ & $1(33.3)$ & $0.0)$ \\
Gentamicin & $1(33.3)$ & $2(66.7)$ & $1(33.3)$ \\
Pefloxacin & $0(0.00)$ & $0(0.0)$ & $1(33.3)$ \\
Ofloxacin & $2(66.7)$ & $0(0.0)$ & $1(33.3)$ \\
Streptomycin & $2(66.7)$ & $\mathbf{4 ( 1 3 . 3 )}$ & $1(33.3)$ \\
\hline Total & $\mathbf{1 7 ( 5 6 . 7 )}$ & $\mathbf{9 ( 3 0 . 0 )}$ \\
\hline
\end{tabular}

Legend: R, Resistant; I, Intermediate; S, Sensitive.

Table 3. Distribution into various resistance phenotypes of antibiotic resistant $E$.coli O157:H7 isolates from diarrhoeic HIVIAIDS patients in Lafia, Central Nigeria.

\begin{tabular}{|c|c|c|c|c|c|}
\hline S/N & Resistance Pattern* & No. (\%) of Isolates & Location & Age Group & Sex** \\
\hline 1 & Cot, Amo, Aug, Ofl, Str & $1(33.3)$ & Urban & $<10$ & M \\
\hline 2 & Spa, Amo, Aug, Gen,Ofl & $1(33.3)$ & Rural & $50>$ & $\mathrm{F}$ \\
\hline 3 & Cot, Chl, Spa, Cip, Amo, Aug, Str & $1(33.3)$ & Urban & $41-50$ & $\mathrm{~F}$ \\
\hline
\end{tabular}

Symbols: * Cot, Cotrimoxazole; Chl, Chloramphenicol; Cip, Ciprofloxacin; Amo, Amoxicillin; Aug, Augmentin; Gen, Gentamicin; Ofl, Ofloxacin;

Str, Streptomycin; Spa, Sparfloxacin.

${ }^{\star \star}$ F, Female; M, Male.

Table 4. Frequency of multiple antibiotic resistance (MAR) and multiple antibiotic resistance indices of E.coli O157:H7 isolates from diarrhoeic HIVIAIDS patients in Lafia, Central Nigeria.

\begin{tabular}{cccc}
\hline $\begin{array}{l}\text { Number of antibiotic to which } \\
\text { isolates are resistant }\end{array}$ & $\begin{array}{c}\text { Number of isolates } \\
\text { with MAR }\end{array}$ & $\begin{array}{c}\text { Frequency } \\
\text { (\%) }\end{array}$ & MAR indices \\
\hline 5 & 2 & 66.7 & 0.5 \\
7 & 1 & 33.3 & 0.7 \\
\hline
\end{tabular}

The cumulative antibiotic resistance frequency of the isolates was $56.7 \%$ as shown in Table 2. The highest $(100 \%)$ resistance was obtained to amoxicillin and Augmentin; while the least was to Pefloxacin (0.0\%) (Table 2).

\section{Antibiotic Resistance Phenotypes}

The distribution of the $E$. coli $\mathrm{O} 157: \mathrm{H} 7$ isolates into different antibiotic resistance phenotypes observed is as given in Table 3. The resistance phenotypes as shown by the isolates are: Cot, Amo, Aug, Ofl, Str; Spa, Amo, Aug, Gen, Ofl and Cot, Chl, Spa, Cip, Amo, Aug, Str with all having the frequency of $33.3 \%$ with respect to patients' gender, location and age group.

\section{Multiple Antibiotic Resistance (MAR) and MAR indices}

Table 4 shows the MAR of the isolates. MAR occurs in all the isolates at different frequencies. MAR indices obtained from this study are 0.5 and 0.7 .

\section{DISCUSSION}

Results from the present study showed a low prevalence (1.9\%) of E.coli 0157: $\mathrm{H} 7$ infection in diarrhoeic HIVIAIDS patients in Lafia, Central Nigeria, thus confirming the presence of this emerging pathogen in this locality. This is the first report of a systematic surveillance study on the prevalence of $E$. coli 0157: $\mathrm{H} 7$ isolated from diarrhoea 
patients in the study area. HIVIAIDS patients have a higher likelihood of developing diarrhoea than people with competent immune systems (Mitchell et al., 1998; Hayes et al., 2003). Studies of diarrhoeal cases have been reported in both immuno-competent and immunosuppressed persons such as those suffering from HIVIAIDS (Obi and Bessong, 2002; Obi et al., 2003; 2006; 2007). However, it is important to recognize that $E$. coli O157: $\mathrm{H} 7$ infections pose the greatest risk to immunosuppressed individuals (Morris and Potter, 1997; Hoffman, 2004).

The prevalence of $E$. coli $\mathrm{O} 157: \mathrm{H} 7$ in patients by gender was of profound epidemiological interest. Out of the 3 patients who were infected with E. coli $\mathrm{O} 157: \mathrm{H} 7$, $66.7 \%(2 / 3)$ were females whereas only a single male $(1 / 3) 33.3 \%$ was infected. The higher prevalence of $E$. coli $\mathrm{O} 157$ in females than in males has been observed in most epidemiological studies. A similar trend was reported in Cameroon in 1998 when an epidemic of diarrhoea due to E. coli O157:H7was investigated (Cunin et al., 1999). Similarly Obong et al. (2008), revealed the same trend among diarrhoeic HIVIAIDS patients in South Africa.

Age distribution among E.coli $\mathrm{O} 157: \mathrm{H} 7$ positive HIVIAIDS patients indicated that age groups from $<10$, 41- 50 and $50>$ had the same prevalence (33.3\%) of $E$. coli $\mathrm{O} 157: \mathrm{H} 7$ infection. This finding is in consonance with the reports by Cunin et al. (1999) and Obong et al. (2008). With respect to locations, prevalence was higher in urban area (66.7\%) followed by suburban area (33.3\%). This was probably because of the proximity and readily access urban inhabitants have to the hospital. More so, the pool of the HIVIAIDS patients in the hospital is from the urban and suburban areas. This could be a reflection of rural-urban migration, which is known to affect most cities universally.

Antimicrobial susceptibilities of the E. coli O157:H7 isolates from HIVIAIDS patients to some commonly used antibiotics revealed that the 3 isolates were resistant to Cotrimoxazole, Chloramphenicol, Ciprofloxacin, Amoxicillin, Augmentin, Gentamicin,Ofloxacin, Streptomycin and Sparfloxacin with the cumulative resistance of $56.7 \%$. High degree of antibiotic resistance by the E. coli O157: $\mathrm{H} 7$ isolates were recorded to Cotrimoxazole, Sparfloxacin, Ofloxacin and Streptomycin $(66.7 \%)$ whereas $100 \%$ resistance were recorded to Amoxicillin and Augmentin.

A very high resistance (84.2 and 100\%) of $E$. coliO157:H7to Amoxycillin was also reported by Reuben and Owuna (2011) and Isibor et al. (2012). Ngwai et al. (2011) reported that $E$. coli isolates from HIVIAIDS patients in Keffi, Nigeria showed a very high degree of resistance (99.2\%) to Augmentin as recorded in this study.

High resistance to cotrimoxazole is in agreement with the finding of Shroeder et al. (2001), who reported that among 189 E. coli O157:H7 isolates recovered from various sources between 1985 and 2000, 19 (10\%) were resistant to this antibiotic. This antimicrobial agent is commonly used to treat respiratory infections, diarrhoea, mastitis, and other infections in beef and dairy cattle which may be consumed by HIVIAIDS patients.

High degree of resistance to quinolones (Sparfloxacin, Ofloxacin) is alarming since they are known to be very potent antimicrobial agents. However some workers have recently reported resistance to the quinolones in Nigeria (Daini et al., 2005; Umolu et al., 2006) as well as in other countries (Oteo et al., 2005). Nevertheless, the relatively lower resistance recorded to Pefloxacin and Ciprofloxacin (fluoroquinolones) shows that they can be used as antibiotic of choice against $E$. coli O157:H7 infections. Prior to their use, resistance was rare (Barry et al., 1990). A previous assessment of some six antibiotics against clinical isolates of $E$. coli showed them to be the most efficacious (Isibor et al., 2003).

The lower resistance of the isolates to gentamicin (an aminoglycoside) could be attributed to its requirement for parenteral administration which hinder their misuse and abuse due the discomfort associated with injections. This finding agrees with that of Reuben and Owuna, (2013) who reported that none of the E. coli $\mathrm{O} 157: \mathrm{H} 7$ isolates tested was resistant to gentamicin. The widespread and inappropriate use of antibiotics is a significant contributing factor to the development and spread of bacterial resistance to antimicrobial agents (Mincey and Parkulo, 2001). For most bacteria, there is evidence that increased usage of a particular antimicrobial correlates with increased levels of bacterial resistance (Granizo et al., 2000).

The observation that some isolates were resistant to Streptomycin but not to gentamicin could be explained by the fact that gentamicin, in addition to binding to a specific S12 protein in the 30 S ribosome, also binds to the L6 protein of the $50 \mathrm{~S}$ ribosome to inhibit protein synthesis (Tripathi, 2003). Hence, a possible alteration of the S12 protein target alone in the streptomycin-resistant isolates is incapable of affecting its action.

In this study, all the E. coli $\mathrm{O} 157: \mathrm{H} 7$ isolates tested showed multidrug resistance to the antibiotics at various percentages. This result is in agreement with the findings by other researchers, who reported multidrug resistance among E. coli O157:H7 isolates (Kim et al., 1994; Schroeder et al., 2002). The 3 isolates were resistant to 5 and 7 of the antibiotics tested. The multiple antibiotic resistance (MAR) indices obtained from this study were 0.5 and 0.7 . The frequency of multiple antibiotic resistance (MAR) has been defined as joint resistance of E. coli isolates to more than two antibiotics (Ngwai et al., 2011). MAR was determined using the formula MAR $=x / y$, where $x$ is the number of antibiotics to which test isolate displayed resistance and $y$ is the total number of antibiotics to which the test organism has been evaluated for susceptibility (Krumperman, 1983; Akinjogunla and Enabulele, 2010). 
According to Krumperman (1983), MAR indices above 0.2 indicate that such isolates originate from environment where antimicrobial agents are freely available and accessible with high potential for abuse. This is true of the study area where people access antibiotics over-the-counter, almost without restrictions. This poses a serious public health concern.

The high MAR indices as recorded in this study also agree with that recorded by Ngwai et al. (2011) and Osibor et al. (2012) in their investigations of multidrug resistant E.coli from HIV patients in Keffi, Nigeria and E. coli O157:H7 from Edo State, Nigeria. Over the last two decades antimicrobial resistance has been reported for all classes of diarrhoeagenic E.coli and specifically from African isolates (Vila et al., 1999). Similar to the high antibiotic resistance pattern observed in this study, Tobih et al. (2006) have also shown that pathogenic isolates of $E$. coli have relatively high potentials for developing resistance.

This study highlights $E$. coli $\mathrm{O} 157: \mathrm{H} 7$, an emerging bacterial pathogen as an aetiologic agent of diarrhoea among HIVIAIDS patients in Lafia, Central Nigeria. The prevalence of $E$. coli $0157: \mathrm{H} 7$ was ubiquitous with respect to patients' gender, age and locations. It is recommended that HIVIAIDS patients with prolonged diarrhoea should be routinely screened for this bacterium. The high degree of antibiotic resistance and MAR indices suggests the need for continuous surveillance of antimicrobial resistance trends in immuno-compromised patients who are highly susceptible to opportunistic infections. Proper implementation and legislation of antibiotics use strategies at all levels will decrease the risk and the clinical threat posed by antimicrobial resistance due to use and misuse of antibiotics.

\section{REFERENCE}

Aboaba OO, Smith SI, Olude FO (2006). Antibacterial effect of edible plant extract on Escherichia coli 0157:H7.Pak. J. Nutr. 5:325-327.

Abong`o BO, Momba MNB, Malakate VK, Mwambakana JN (2008). Prevalence of Escherichia coli O157:H7 among Diarrhoeic HIVIAIDS Patients in the Eastern Cape Province-South Africa. Pak. J. Biol. Sci. 11: 1066-1075.

Adwan K, Abu-hasan N, Essawi T, Bdir M (2002). Isolation and characterization of shiga toxigenic Escherichia coli strains from northern Palestine. J. Med. Microbiol. 51(4): 332-5.

Aibinu IE, Peters RF, Amisu KO, Adesida SA, Ojo MO, Tolu O (2007). Multidrug Resistance in E. coli O157 Strains and the Public Health Implication. J. Animal Sci. 3(3): 22-33.

Akinjogunla OJ, Enabulele OI (2010). Virulence factors, plasmid profiling and curing analysis of multidrug resistant Staphylococcus aureus and coagulase negative Staphylococcus spp isolated from patients with acute otitis media. J. Am. Sci. 6 (11): 1022-1033.

Bettelheim KA, Beutin L (2003). Rapid laboratory identification and characterization of verotocytoxigenic (Shiga toxin producing) Escherichiacoli (VTEC/STEC). J. Appl. Microbiol. 95: 205-217.

Chapman PA, Siddons CA, Cerdan-Malo AT, Harkin AM (1997). A 1Year Study of $E$. coli O157:H7 in Cattle, Sheep, Pigs and Poultry. J. Epidemiol. Infect. 119: 245-250.

Cho S, Diez-Gonzales F, Fossler CP, Wells SJ, Hedberg CW, Kaneene JB (2006). Prevalence of Shiga Toxin-Encording Bacteria and
Shiga-Producing E. coli Isolates from Dairy Farms and Country Fair. Vet. Microbiol. 118: 289-298.

Clinical and Laboratory Standard Institute (CLSI) (2007). Performance Standards for Antimicrobial SusceptibilityTesting. Seventeenth Informational Supplement. ApprovedStandard M100-S17: Wayne, $P A$

Daini OA, Ogbolu OD, Ogunledun A (2005). Quinolones resistance and R- Plasmids of some Gram-negative enteric bacilli. Afr. J. Clin. Exp. Microbiol. 6(1):14-20.

Fitzpatrick M (1999). Haemolytic Uraemic Syndrome and E.coli 0157. Prevention rests with sound public health measures. Br. Med. J. 318:684-685.

Galane PM, Le Roux M (2001). Molecular Epidemiology of Escherichia coli isolated from young South Africa children with diarrhoeal diseases. J. Health Population Nutr. 19(1): 311-338.

Granizo JJ, Aguilar L, Casal J, Dal-Re R, Baquero F (2000). Streptococcus pyrogenes resistance to erythromycin in relation to macrolide consumption in Spain (1986-1997). J. Antimicrob. Chemother. 46: 959 - 964.

Griffin PM, Tauxe RV (1991). The epidemiology of infections caused by Escherichia coli O157: $\mathrm{H} 7$, other enterohaemorrhagic E. coli, and the associated hemolytic uremic syndrome. Epidemiol. Rev. 13:6098.

Hayes CE, Elliot EK, Goulda, D.(2003). Food and water safety for persons infected with human immunodeficiency virus. J. Clin. Infect. Dis. 36: S106-S109.

Hoffman EW (2004). Evaluation of Food Safety Education Materials for Persons with HIVIAIDS. Masters' Thesis. Washington State University. United States of America. $165 \mathrm{pp}$.

Isibor JO, Erhunmwuns PI, Nwobu GO (2003). Antimicrobial susceptibility of clinical isolates of $E$. coli to six antimicrobial agents. J. Appl. Basic Sci. 1(1and 2):37-40.

Isibor JO, Ekundayo AO (2012).Determination of the Antibiotic Susceptibility Patterns of Local Isolates of E. coli O157:H7 from Edo State, Nigeria. New York Sci. J. 5(10): 151-157

Krumperman PH (1983). Multiple antibiotic resistance indexing of Escherichia coli to identify high-risk sources of faecal contamination of foods. J. Appl. Environ Microbiol. 46:165-170.

Mincey BA, Parkulo MA (2001). Antibiotic prescribing practices in a teaching clinic: comparison of resident and staff physicians. Southern Med. J. 94(4): 365 - 369.

Mitchell DK, Snyder J, Pickering LK (1998). Gastrointestinal Infections. In: Paediatric AIDS: The Challenge of HIV Infection in Infants, Children and Adolescents, Pizzo, P.A. and C.M. Wilfert (Ed.). 3rd Edn., Williams and Wilkins, Baltimore, MD., pp: 267-291.

Morris JG, Potter M (1997). Emergence of new pathogens as a function of changes in host susceptibility. Emerg. Infect. Dis. 3: 435-441.

Molbak K, Mead PS, Griffin PM (2002). Antimicrobial Therapy in Patients with Escherichia coli O157:H7 Infection. J. Am. Med. Assoc. 288:1014-6.

National HIVIAIDS Reproductive Health Survey (2012). Nigeria HIV Prevalence rate. Gotten from: http://naca.gov.ng/new/ on $26^{\text {th }}$ July, 2015.

Ngwai YB, Nwankwo HN, Adoga MP (2011). Multidrug resistant Escherichia coli from human immunodeficiency virus/acquired immunodeficiency syndrome (HIVIAIDS) patients in Keffi, Nigeria. Int. Res. J. Microbiol. 2(4):122-125

Obi CL, Bessong PO (2002). Diarrhoeagenic bacterial pathogens in HIV positive patients with diarrhoea in rural communities of Limpopo Province, South Africa. J. Health Population Nutr. 20(3): 230-234.

Obi CL, Potgieter N, Bessong PO, Igumbor EO, Green E (2003) Prevalence of pathogenic bacteria and retroviruses in the stools of patients presenting with diarrhoea from rural communities in Venda, South Africa. South Afr. J. Sci. 99:589-591.

Obi CL, Onabulu B, Onabulu B, Igumbor EO, Ramalivhana J, Bessong PO, Van Rensburg EJ, Lukoto M, Green E, Ndou S, Mulaudzi TB (2006). The interesting cross-paths of HIVIAIDS and water in Southern Africa with special reference to South Africa. Water SA 32(3) 322-344.

Obi CL, Ramalivhana J, Momba MNB, Onabulu B, Igumbor EO, Lukoto M, Mulaudzi TB, Van Rensburg EL, Green E, Ndou S (2007). 
26 Int. Res. J. Microbiol.

Antibiotic resistance profiles and relatedness of enteric bacterial pathogens isolated from HIVIAIDS patients with and without diarrhoea and their household drinking water in rural communities in Limpopo Province South Africa. Africa J. of Biotechnology, 6(8) 1035-1047.

Okeke IN, Edelman R (2001). Dissemination of antibiotic resistant bacteria across geographic borders. J. Clin. Infect. Dis. 33: 364369.

Oteo J, Lazaro E, de Abjo FJ, Baquero F, Campos J (2005). Spanish members of EARSS. Antimicrobial-resistant invasive Escheri chiacoli, Spain. Emerg. Infect. Dis. 11 (4): 546- 553.

Reuben CR, Owuna G (2013). Antimicrobial Resistance Patterns of Escherichia coli O157:H7 from Nigerian Fermented Milk Samples in Nasarawa State, Nigeria. Int. J. Pharmaceutical Sci. Invent. 2(3): 38-44.

Riley LW, Remis RS, Helgerson SD (1983). Haemorrhagic colitis associated with a rare E.coli serotype. N. Engl. J. Med. 308:681685.
Sapkota D, Ghimire P, Manandhar S (2004). Enteric parasitosis in patients with human immunodeficiency virus (HIV) infections and acquired immunodeficiency syndrome (AIDS) in Nepal. J. Nepal Health Res. Council. 2 (1) 1-6.

Tripathi KD (2003). Essentials of Medical Pharmacology. Ed 5th. Jaypee Brothers Med. Publishers (P) Ltd: New Delhi. Pp. 627-678.

Umolu PI, Omigie O, Tatfeng Y, Omorogbe FI, Aisabokhale F, Ugbodagah OP (2006). Antimicrobial susceptibility and plasmid profiles of Escherichiacoli isolates obtained from different human clinical specimens in Lagos - Nigeria. Am. J. Sci. 2(4): 70-76.

Wilson JB, Johnson RP, Clarke RC, Rahn K, Renwick SA, Alves D (1997). Canadian perspectives on verocytotoxin-producing infection. J. Food Protect. 60: 1451-1453. 